\title{
Seismically induced soft-sediment deformation in crevasse-splay microdelta deposits (Middle Miocene, central Poland) - reply
}

\author{
Lilianna CHOMIAK ${ }^{1}$, Piotr MACIASZEK ${ }^{1}$, Robert WACHOCKI ${ }^{2}$, \\ Marek WIDERA ${ }^{1, *}$ and Tomasz ZIELIŃSKI ${ }^{1}$
}

1 Adam Mickiewicz University, Institute of Geology, Krygowski 12, 61-680 Poznań, Poland

2 Konin Lignite Mine, 9 600-lecia Avenue, 62-540 Kleczew, Poland

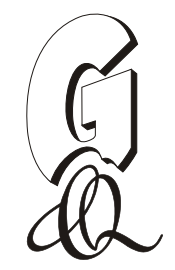

Chomiak, L., Maciaszek, P., Wachocki, R., Widera, M., Zieliński, T., 2019. Seismically-induced soft-sediment deformation in crevasse-splay microdelta deposits (Middle Miocene, central Poland) - reply. Geological Quarterly, 63 (2): 429-433, doi: 10.7306/gq. 1477

Associate editor: Anna Wysocka

We expected that our paper on the crevasse-splay microdelta (Chomiak et al., 2019) would arouse the interest of other researchers for at least two reasons. First, this is the first such palaeoform discovered and described within the Mid-Miocene lignite seam in Poland. Second, the microdelta siliciclastic deposits are strongly deformed both ductile and brittle. Therefore, we would like to thank Tom van Loon for his effort to comment on our article, including his words of appreciation, and above all, for pointing out some of the terminological and interpretative shortcomings. Our reply will be in line with the issues discussed in his comment.

Key words: tectonic graben, lignite seam, SSDS, domino structures, tectonics, seismics.

\section{INTRODUCTION}

Crevasse-splay sequences are known from ancient, but mainly from modern sedimentary environments. In the latter case, they can be examined in great detail both when they were forming (initial phase of flooding) and when the floodwaters drained back into the river channels (e.g., Smith et al., 1989; Zwoliński, 1992; Pérez-Arlucea and Smith, 1999; Farrell, 2001; Gębica and Sokołowski, 2001; Gouw and Autin, 2008; Van Toorenenburg et al., 2018 and references therein). Some crevasse splays are accumulated predominantly in stagnant water (ponds, lakes), forming so-called crevasse-splay microdeltas (e.g., Teisseyre, 1985; Bristow et al., 1999; Cahoon et al., 2011; Ciarcia and Vitale, 2013; Zieliński, 2014 and references therein). The situation is completely different in the case of a rock record in which siliciclastics are rarely interpreted as representing crevasse splays (e.g., Horne et al., 1978; Guion, 1984; Fielding, 1986; Kasiński, 1986; Kirschbaum and McCabe 1992; Flores, 1993; Davies-Vollum and Kraus, 2001; Burns et al., 2017) or crevasse-splay microdeltas (e.g., Michaelsen et al., 2000) based on limited data obtained mainly from borehole

\footnotetext{
* Corresponding author, e-mail: widera@amu.edu.pl
}

Received: May 21, 2019; accepted: May 25, 2019; first published online: June 5, 2019 profiles. Most of the studies come from research on coal-bearing formations containing hard coal or lignite. Thus, we expected to find (under favourable mining conditions) the occurrence of crevasse-splay deposits in Polish lignite mines as well. First, we discovered undeformed siliciclastics with sedimentary breccia resting on the top of a crevasse-splay body in the Tomisławice opencast - Konin Lignite Mine in central Poland (Widera, 2016a, 2017; Widera et al., 2017). Similar findings were only a matter of time. In 2018 , we discovered a relatively widespread layer of sands, with a small amount of organic matter, splitting the lignite seam in the nearby Jóźwin IIB opencast, which also belongs to the Konin Lignite Mine. Surprisingly, these siliciclastic deposits were typical of a crevasse-splay microdelta, and were strongly deformed both plastic and brittle. The co-occurrence of such deposits and deformations is unknown from the Polish lignite-bearing areas and probably from other coal/lignite-bearing regions in the world. Therefore, we concluded that they were worth describing and interpreting (Chomiak et al., 2019). Opinion convinced us of the need of our interlocutor, van Loon, who claimed that these sediments are "...a type of sediment that seems largely undervalued in sedimentology. Relatively little is still known about these deposits if compared to most other types of sediment,..." (Van Loon, 2019).

The crevasse-splay sediments discussed are situated within the first Mid-Polish (first Lusatian) lignite seam, which belongs to the lower part of the Poznań Formation - the youngest Neogene lithostratigraphic unit in central Poland (Widera, 2007). This lignite accumulated in the backswamp area of a Middle Miocene low-ly- 
ing mire, as evidenced by, inter alia, the occurrence of deposits of a crevasse-splay microdelta (Chomiak et al., 2019). In general, the study area covers the shallow fault-bounded Kleczew Graben, where the Mesozoic bedrock, built of carbonate rocks (limestone and marl), is located several tens of metres deep in the axial zone of the graben. It seems important, in the context of the sedimentary and deformational origin under discussion, that the accumulation of the lignite/peat in the study area was coincident with tectonic subsidence (synsedimentary tectonics) of up to $20 \mathrm{~m}$ (Widera, 2007; Chomiak et al., 2019). Obviously, this is small compared to the Kleszczów Graben mentioned by the interlocutor, where the depth of the tectonic depression reaches $550 \mathrm{~m}$, and the continuous thickness of the main lignite seam is over 250 m (Piwocki, 1992; Widera, 2013). Hence, we fully agree with the opinion that "...synsedimentary tectonics can cause abundant soft-sediment deformation structures (SSDS), although they cannot always with certainty be attributed to seismic activity..." (see Van Loon, 2019). Similarly, his statement that "... numerous analyses of SSDS have convincingly made clear that sediments need not be lithified to show brittle behaviour; on the contrary, even water-saturated, completely (geologically) fresh sediments can show significant faulting..." is undoubtedly true. However, it is confusing for us that at the time of tectonic activity "...they were consolidated but not yet lithified." In this case, we can say with certainty that the crevasse-splay microdelta deposits under discussion were not consolidated in the Middle Miocene nor are they currently consolidated. In fact, they are still loose and only slightly compacted (Chomiak et al., 2019).

\section{DOMINO STRUCTURES}

The terms "domino-type deformations", "domino-style geometry" and "domino-type brecciation" was used in our paper in a purely descriptive sense. It meant that the sandy clasts in the brecciated layers looked like domino cubes or blocks (see Chomiak et al., 2019, their fig. 9C and the text). They are, in fact, known as 'domino boudins' in structural geology and are a widely accepted kinematic classification of Goscombe et al. (2004). However, other names to describe such deformational structures were, and still are in use, e.g., "domino-style faults" (e.g., McClay and Ellis, 1987), "fault blocks" or "rotated fault blocks" (Vendeville, 1991), "domino fault blocks" (Stewart and Argent, 2000), "domino-type structures" (e.g., Markiewicz and Becker, 2009; Cymerman, 2014), "tilt blocks" (Jackson and Hudec, 2017), etc. In our opinion, most of these names are understandable to the reader who is familiar with all kinds of deformation. However, we do not see any indications to the contrary for one of the deformations described by us to be named "domino boudins", as proposed by van Loon (2019).

Apart from terminological issues, the presence of domino boudins (domino-type deformations) in the crevasse-splay microdelta deposits is a more important result. In our paper (Chomiak et al., 2019), we treated these deformations as a part of the breccia, and not separate from it. Therefore, this discussion provides a good opportunity to make up for our previous shortcoming because "these structures consequently deserve some more attention" (Van Loon, 2019). It should be noted that domino boudins are known from geodynamic settings of various ages and different scales, i.e. from mineral-grain to continental-crustal scales. They are present in all types of rocks and could form in both brittle and ductile-brittle conditions (e.g., McClay and Ellis, 1987; Vendeville, 1991; Goscombe et al., 2004; Dąbrowski and Grasemann, 2014; Jackson and Hudec, 2017 and references therein). Moreover, as our interlocutor writes "they have also been mentioned from slumped masses in the mainly calcareous Late Pleistocene Lisan Formation in Israel (Alsop and Marco, 2011), but it should be noticed that these rocks now are more commonly considered to represent seismically deformed sediments, originated in the Dead Sea Graben, and thus in a setting that is comparable with that of the sediments described by Chomiak et al. (2019). As far as known, only one single study (Yang and van Loon, 2016) has mentioned domino boudins from a Cretaceous (hard-rock) succession that must have been unlithified when the deformation occurred (Figs. 1 and 2)" (see Van Loon, 2019). These beautiful high-quality photographs, adapted from Yang and van Loon (2016), do not fully correspond to what we have shown in figure 9C (Chomiak et al., 2019). Most of our domino boudins (as originally created, as they are now) are a steeply sloping (up to $25^{\circ}$ ) layer of sand. On the contrary, the domino boudins presented in photographs attached by van Loon (2019: figs. 1 and 2) lie horizontally.

The most important thing in the two aforementioned examples of domino boudins is that they can be used in the kinematic analysis. In other words, such asymmetric boudins may be helpful as shear sense indicators (e.g., Goscombe et al., 2004; Dąbrowski and Grasemann, 2014). Therefore, we will now address it in more detail than was done in our previous paper. The interpretation of the origin of domino boudins shown in figure $9 \mathrm{C}$ (Chomiak et al., 2019) is supported by a graphical explanation of this process (Figs. 1 and 2). There are two possibilities for the formation of dominos in an extensional setting (Stewart and Argent, 2000). In both cases, the sedimentary multilayers are tilted, characterized by varying rheology (sands vs coaly
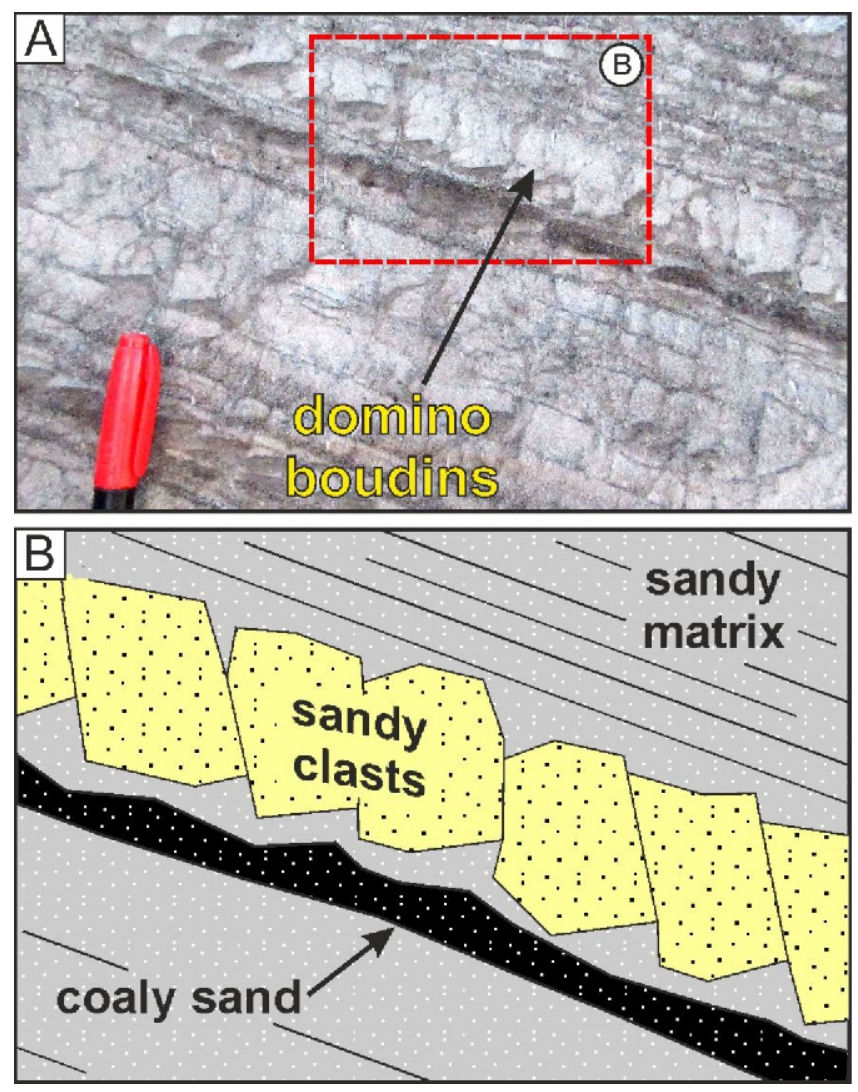

Fig. 1. Domino boudins defined by Chomiak et al. (2019) as the domino-type deformations

A - the same photograph that Chomiak et al. (2019) presented in their figure $9 \mathrm{C}$; $\mathbf{B}$ - interpretative sketch of a fragment of the photograph marked in Figure $1 \mathrm{~A}$ 


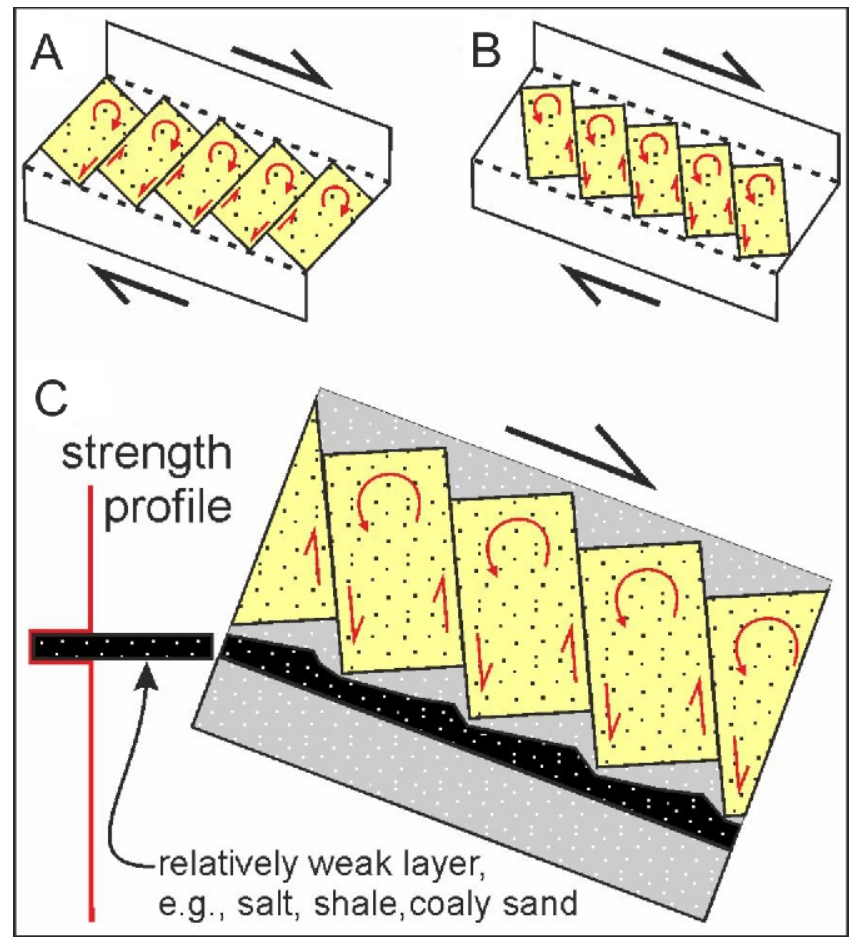

Fig. 2. Models depicting synthetic and antithetic rotation of domino boudins developing in the same overall shear sense (modified from Stewart and Argent, 2000)

A - synthetic rotation of dominos and antithetic shear between them (without basal detachment); B - antithetic rotation of dominos and synthetic shear between them (with basal detachment); C - explanation for the formation of the domino boudins shown in Figure 1 and by Chomiak et al. (2019) in their figure 9C; note that the sediment layers are tilted and a relatively weak (coaly sand) bed in relation to the sandy layers is present at the base of dominos

sands), and their extension is induced by gravity. As the trigger mechanism, we obviously recognize that seismic shocks were caused by Mid-Miocene tectonic activity in the study area (Chomiak et al., 2019). The first case is when there is no displacement between the domino layer and the underlying layer. In this case, the dominoes were tilted (rotated) synthetically according to the inclination of the beds (Fig. 2A). A different situation occurs if a relatively weak layer was present at the base of the domino boudins (e.g., coaly sand), along which there was a detachment. In this case, the dominos were set antithetically (Fig. 2B, C). Thus, under the same overall shear sense the domino boudins can be tilted in the opposite direction depending on the presence or absence of a basal detachment. The second example discussed above and shown in Figure $2 \mathrm{C}$ closely corresponds to what is shown in Figure 1 and depicted by Chomiak et al. (2019) in their figure 9C. It must be added that such dominos (antithetically rotated) are known from numerous geological examples (e.g., Stewart and Argent, 2000 Goscombe et al., 2004; Jackson and Hudec, 2017) and sandbox models (e.g., McClay and Ellis, 1987; Vendeville, 1991). Summarizing this section, we disagree with the statement that "...they do not come to the same conclusion that structural geologists tend to come to when they find such a structure" (Van Loon, 2019). The above explanations show that structural geologists reach the same conclusions by analyzing structures similar (in the sense of the geometry and rheology of the sediments) to those we studied (cf. Figs. 1 and 2).

\section{TECTONICS VERSUS SEISMICS}

Indeed, in our original paper (Chomiak et al., 2019) we combined all of the studied soft-sediment deformation structures (SSDS) with seismites. However, van Loon (2019) states that "...the SSDS in these layers should therefore not be called seismites...". We still believe that these deformations arose as a result of seismic activity caused by tectonic movements in the Kleczew Graben area. The term 'seismites' has been used by us in a general sense for all SSDS studied. Furthermore, we did not find any evidence that these SSDS were "...deformed again later by other processes" (Van Loon, 2019).

Reading the commentary by van Loon (2019), we came to the conclusion that the issue of a sudden increase in pore-water pressure in the backswamp area was explained ambiguously. Hence, we want to explain that the groundwater table rise, following a strong earthquake, was relative. It means that the sediments of the crevasse-splay microdelta were subjected to tectonic lowering (i.e., collapse reaching the Mesozoic bedrock, and maybe even the Permian salts) by a few decimetres (see Chomiak et al., 2019, their figure 10D). In our opinion, this could cause water to flow towards the top of the sediments, leading to their deformation. A similar situation may have occurred during the flood, when rising water levels in the river channel caused the groundwater table to rise in the overbank (backswamp) area. Due to the slowness of this process in relation to the sudden tectonic collapse, we have not discussed this possibility in our paper (Chomiak et al., 2019). Unfortunately, we have found no record of sand blows in the rock, as shown by van Loon (2019: fig. 4), or related sand dykes. They would be very strong evidence of the seismic origin of deformations caused by tectonic movements such as those produced by earthquakes (Sims and Garvin, 1995). On the other hand, the presence of these forms and structures excludes the areal and uniform (not point or linear) rising and outflow of water necessary for the formation of widespread hydraulic fracturing (e.g., Obermeier et al., 2005) in the case of the breccia.

We consider the aforementioned tectonic collapse the result of karstic processes as suggested by one of the reviewers. This is justified by the fact that such large collapses often cause SSDS (e.g., Moretti et al., 2011). Maybe we did not express it clearly and confused our interlocutor who asks "...why would karst-like dissolution occur in an organic-rich sandy layer?" (Van Loon, 2019). Obviously, the karstification process would only cover the Mesozoic top, which is composed of carbonates, not organic-rich sands. In fact, only a few layers contain $>1$ wt. \% of organic matter (Fig. 1). We have not found the effects of karst processes in the research area and, therefore, we rejected its influence on the formation of the SSDS investigated. However, effects of the karstification process in the form of karst caverns are known from other Polish lignite-bearing areas, for example from the Złoczew Graben (Kasiński, 2015) and the Kleszczów Graben mentioned in the introductory section (Widera, 2016b, and references therein).

\section{FINAL REMARKS}

Our paper (Chomiak et al., 2019), at least partly, fills a gap in the geological literature on crevasse-splay microdeltas and their deformation in the rock record. However, we realize that not everything was convincingly explained, and some issues were described in an ambiguous way. That is why we thank the commentary by van Loon (2019) for the opportunity to clarify a few of the most debatable issues once again. Some of them will 
remain the subject of discussion for the future. Thus, the best summary of this reply seems to be the words of our interlocutor who states that "...the descriptions and analyses of SSDS are scattered over almost all types of earth-science literature, which makes it almost impossible to keep up with new insights. The most effective way is probably writing some comments that may be found by readers who are interested in the material that is commented upon" (Van Loon, 2019).

\section{REFERENCES}

Alsop, G.I., Marco, S., 2011. Soft-sediment deformation within seismogenic slumps of the Dead Sea Basin. Journal of Structural Geology, 33: 433-457.

Bristow, C.S., Skelly, R.L., Ethridge, F.G., 1999. Crevasse splays from the rapidly aggrading, sand-bed, braided Niobrara River Nebraska: effect of base-level rise. Sedimentology, 46: 1029-1047.

Burns, C., Mountney, N.P., Hodgson, D.M., Colombera, L., 2017. Anatomy and dimensions of fluvial crevasse-splay deposits: examples from the Cretaceous Castlegate Sandstone and Neslen Formation, Utah, U.S.A. Sedimentary Geology, 351: 21-35.

Cahoon, D.R., White, D.A., Lynch, J.C., 2011. Sediment infilling and wetland formation dynamics in an active crevasse splay of the Mississippi River delta. Geomorphology, 131: 57-68.

Chomiak, L., Wachocki, R., Maciaszek, P., Widera, M., Zieliński, T., 2019. Seismically-induced soft-sediment deformation in crevasse-splay microdelta deposits (Middle Miocene, central Poland). Geological Quarterly, 63 (1): 162-177.

Ciarcia, S., Vitale, S., 2013. Sedimentology, stratigraphy and tectonics of evolving wedge-top depozone: Ariano Basin, southern Apennines, Italy. Sedimentary Geology, 290: 27-46.

Cymerman, Z., 2014. Structural and kinematic analysis and the Mesoproterozoic tectonic evolution of the Suwałki Massif and its surroundings (NE Poland) (in Polish with English summary). Prace Państwowego Instytutu Geologicznego-Państwowego Instytutu Badawczego, 201.

Davies-Vollum, K.S., Kraus, M.J., 2001. A relationship between alluvial backswamps and avulsion cycles: an example from the Willwood Formation of the Bighorn Basin, Wyoming. Sedimentary Geology, 140: 235-245.

Dąbrowski, M., Grasemann, B., 2014. Domino boudinage under layer-parallel simple shear. Journal of Structural Geology, 68A: 58-65.

Farrell, K.M., 2001. Geomorphology, facies architecture, and high-resolution, non-marine sequence stratigraphy in avulsion deposits, Cumberland Marshes, Saskatchewan. Sedimentary Geology, 139: 93-150.

Fielding, C.R., 1986. Fluvial channel and overbank deposits from the Westphalian of the Durham coalfield, NE England. Sedimentology, 33: 119-140.

Flores, R.M., 1993. Geologic and geomorphic controls of coal development in some Tertiary Rocky Mountain basins, USA. International Journal of Coal Geology, 23: 43-73.

Gębica, P., Sokołowski, T., 2001. Sedimentological interpretation of crevasse splays formed during the extreme 1997 flood in the upper Vistula river valley (South Poland). Annales Societatis Geologorum Poloniae, 71: 53-62.

Goscombe, B.D., Passchier, C.W., Hand, M., 2004. Boudinage classification: endmember boudin types and modified boudin structures. Journal of Structural Geology, 26: 739-763.

Gouw, M.J.P., Autin, W.J., 2008. Alluvial architecture of the Holocene Lower Mississippi Valley (U.S.A.) and a comparison with the Rhine-Meuse delta (The Netherlands). Sedimentary Geology, 204: 106-121.

Guion, P.D., 1984. Crevasse splay deposits and roof-rock quality in the Three Quarters Seam (Carboniferous) in the East Midlands Coalfield, U.K. Sedimentology of Coal and Coal-bearing Sequences. International Association of Sedimentologists, Special Publication, 7: 291-308.
Horne, J.C., Ferm, J.C., Caruccio, F.T., Baganz, B.P., 1978 Depositional models in coal exploration and mine planning in Appalachian Region. American Association of Petroleum Geologist Bulletin, 62: 2379-2411.

Jackson, M., Hudec, M., 2017. Salt-Tectonic Systems. Cambridge University Press, Cambridge.

Kasiński, J.R., 1986. Sedimentary models of small lignite deposits: examples from the Polish Neogene (in Polish with English summary). Przegląd Geologiczny, 34: 189-197.

Kasiński, J.R., 2015. The karst phenomena in the Mesozoic basement of the Złoczew lignite deposits against structures of the Poznań-Kalisz fault zone (in Polish). In: Proceedings of the IV National Scientific Conference. Mineral Deposits: the Prospection, Exploration, Documentation (ed. M. Pańczyk): 31-32. Państwowy Instytut Geologiczny, Warszawa.

Kirschbaum, M.A., McCabe, P.J., 1992. Controls on the formation of coal and on the development of anastomosed fluvial systems in the Cretaceous Dakota Formation of southern Utah. Sedimentology, 39: 581-598.

Markiewicz, A., Becker, R., 2009. The original extent of the Oldest Halite (Na1) in the southern part of the Fore-Sudetic Monocline (SW Poland) (in Polish with English summary). Geologia, 35: 327-348.

McClay, K.R., Ellis, P.G., 1987. Geometries of extensional fault systems developed in model experiments. Geology, 15: 341-344.

Michaelsen, P., Henderson, R.A., Crosdale, P.J., Mikkelsen, S.O., 2000. Facies architecture and depositional dynamics of the Upper Permian rangal coal measures, Bowen Basin, Australia. Journal of Sedimentary Research, 70: 879-895.

Moretti, M., Owen, G., Tropeano, M., 2011. Soft-sediment deformation induced by sinkhole activity in shallow marine environments: a fossil example in the Apulian Foreland (Southern Italy). Sedimentary Geology, 235: 331-342.

Obermeier, S.F., Olson, S.M., Green, R.A., 2005. Field occurrences of liquefaction-induced features: a primer for engineering geologic analysis of paleoseismic shaking. Engineering Geology, 76: 209-234.

Pérez-Arlucea, M., Smith, N.D., 1999. Depositional patterns following the 1870s avulsion of the Saskatchewan River (Cumberland Marshes, Saskatchewan, Canada). Journal of Sedimentary Research, 69: 62-73.

Piwocki, M., 1992. Extent and correlations of main groups of the Tertiary lignite seams on Polish platform area (in Polish with English summary). Przegląd Geologiczny, 40: 281-286.

Sims, J.D., Garvin, C.D., 1995. Recurrent liquefaction at Soda Lake, California, induced by the 1989 Loma Prieta earthquake, and 1990 and 1991 aftershocks: implications for paleoseismicity studies. Seismological Society of America Bulletin, 85: 51-65.

Smith, N.D., Cross, T.A., Dufficy, J.P., Clough, S.R., 1989. Anatomy of an avulsion. Sedimentology, 36: 1-23.

Stewart, S.A., Argent, J.D., 2000. Relationship between polarity of extensional fault arrays and presence of detachments. Journal of Structural Geology, 22: 693-711.

Teisseyre, A.K., 1985. Recent overbank deposits of the Sudetic valleys, SW Poland. Part I: General environmental characteristics (with examples from the upper River Bóbr drainage basin) (in Polish with English summary). Geologia Sudetica, 20: 113-195.

Van Loon, A.J., 2019. Seismically-induced soft-sediment deformation in crevasse-splay microdelta deposits (Middle Miocene, 
central Poland) - comment. Geological Quarterly, 63 (2): 424-428.

Van Toorenenburg, K.A., Donselaar, M.E., Weltje, G.J., 2018. The life cycle of crevasse splays as a key mechanism in the aggradation of alluvial ridges and river avulsion. Earth Surface Processes and Landforms, 43: 2409-2420.

Vendeville, B., 1991. Mechanisms generating normal fault curvature: a review illustrated by physical models. Geological Society Special Publication, 56: 241-249.

Yang, R., van Loon, A.J., 2016. Early Cretaceous slumps and turbidites with peculiar soft-sediment deformation structures on Lingshan Island (Qingdao, China) indicating a tensional tectonic regime. Journal of Asian Earth Sciences, 129: 206-219.

Widera, M., 2007. Lithostratigraphy and Palaeotectonics of the sub-Pleistocene Cenozoic of Wielkopolska (in Polish with English summary). Adam Mickiewicz University Press, Poznań.

Widera, M., 2013. Changes of the lignite seam architecture - a case study from Polish lignite deposits. International Journal of Coal Geology, 114: 60-73
Widera, M., 2016a. Depositional environments of overbank sedimentation in the lignite-bearing Grey Clays Member: new evidence from Middle Miocene deposits of central Poland. Sedimentary Geology, 335: 150-165.

Widera, M., 2016b. Genetic classification of Polish lignite deposits: a review. International Journal of Coal Geology, 158: 107-118.

Widera, M., 2017. Sedimentary breccia formed atop a Miocene crevasse-splay succession in central Poland. Sedimentary Geology, 360: 96-104.

Widera, M., Chomiak, L., Gradecki, D., Wachocki, R., 2017. Crevasse splay deposits from the Miocene of central Poland near Konin (in Polish with English summary). Przegląd Geologiczny, 65: 251-258.

Zieliński, T., 2014. Sedimentology. River and Lake Deposits (in Polish). Adam Mickiewicz University Press, Poznań.

Zwoliński, Z., 1992. Sedimentology and geomorphology of overbank flows on meandering river floodplains. Geomorphology, 4: 367-379. 